Fall 2009

\title{
Pedagogies that foster transformative learning in a multicultural education course: A Reflection
}

\author{
Omiunota Nelly Ukpokodu \\ University of Missouri-Kansas City
}

Follow this and additional works at: https://digitalscholarship.unlv.edu/jpme

\begin{abstract}
Repository Citation
Ukpokodu, Omiunota Nelly (2009) "Pedagogies that foster transformative learning in a multicultural education course: A Reflection," Journal of Praxis in Multicultural Education: Vol. 4: No. 1, Article 4. DOI: 10.9741/2161-2978.1003

Available at: https://digitalscholarship.unlv.edu/jpme/vol4/iss1/4
\end{abstract}

This Article is protected by copyright and/or related rights. It has been brought to you by Digital Scholarship@UNLV with permission from the rights-holder(s). You are free to use this Article in any way that is permitted by the copyright and related rights legislation that applies to your use. For other uses you need to obtain permission from the rights-holder(s) directly, unless additional rights are indicated by a Creative Commons license in the record and/ or on the work itself.

This Article has been accepted for inclusion in Journal of Praxis in Multicultural Education by an authorized administrator of Digital Scholarship@UNLV. For more information, please contact digitalscholarship@unlv.edu. 


\title{
Pedagogies that Foster Transformative Learning in a Multicultural Education Course: A Reflection
}

\author{
Omiunota Nelly Ukpokodu
}

\begin{abstract}
This paper reports on a qualitative study that investigated pedagogies that foster transformative learning in a multicultural education course. In this study, teachers identified the following as pedagogies that fostered their learning transformation and moved them from color-blindness to color-vision: (1) dialogic relationships in a learning community, (2) writing pre-post narrative inquiries, (3) engagement in structured and threaded online discussions, (4) critical textual discourse, (5) experiential activities, and (6) experiencing a humanizing pedagogy.
\end{abstract}

Today, it is crystal clear that teaching in any U.S. school and classroom is a cross-cultural reality, in that teachers and their students differ remarkably in terms of race, ethnicity, gender, class, language, exceptionalities, etc. In the last three decades, this reality has necessitated the need to require diversity courses that are designed to help prospective and inservice teachers develop the knowledge, skills, and dispositions needed for successfully working with diverse student populations, as well as preparing all students for effective citizenship in a multicultural democracy. However, the literature reveals that most approaches used in diversity courses have not produced the expected outcomes, that preservice and inservice teachers who enroll in these courses tend to exhibit resistance and defensiveness that negate their ability to experience transformative learning (Ahlquist, 1991; Howard, 2006; Ladson-Billings, 2000; Tatum, 1992; Ukpokodu, 2002). The course was designed to challenge students to (1) engage in deconstructing the educational system within a historical, cultural, and political context, (2) explore issues of equity, social justice, and socially just teaching, (3) examine self in terms of their assumptions, beliefs, values, and knowledge, (4) construct new lenses and perspectives about self, others, and praxis, and (5) cultivate visions of hope and possibilities for transformative practice and change agency. In this qualitative research, I examine, analyze, and reflect on pedagogies that broke down students' resistance and engender transformative learning.

Omiunota Nelly Ukpokodu is an associate professor in the School of Education at the University of Missouri-Kansas City. Her research interests include transformative pedagogy and learning, quality teacher preparation, multicultural education-teaching for diversity, equity, and social justice, urban education, citizenship, and global education.

\section{Transformative Learning and Pedagogy}

This study draws on the literature on transformative learning and pedagogy. Over the years research has informed us that the purpose of learning is to effect change in the learner (Dewey, 1933; Mezirow, 2000). As John Dewey (1933) explains, transformative learning is when a person comes to see some aspect of the world in a new way; when he/she finds new meaning, and values it. Jack Mezirow (2000) defines transformative learning, as a process whereby "we transform our taken-for-granted frames of reference to make them more inclusive, discriminating, open, [changeable], and reflective so that they may generate beliefs and opinions that will prove more true or justified to guide action" (p.214). For Mezirow, our meaning structures-frames of reference-consist of two dimensions; "habits of mind" and "points of view" (Wiessner \& Mezirow, 2000, p. 345). Thus, for learning transformation to occur, individuals must become aware of their current habits of mind and points of views, but more importantly, engage in examining, reflecting, and challenging their assumptions and premises for the mind-sets, and developing alternative perspectives. Further, he explains that, to effect a change in learning, students would have to alter their frames of reference by critically reflecting on their assumptions and beliefs and consciously making and implementing plans that bring about new ways of defining their worlds and understanding. The theory of transformative learning is concerned with how learners critically reflect on experiences including existing knowledge and beliefs and how they integrate new knowledge to reflect a change in experience. For most proponents, transformative learning is rooted in experience (Dewey, 1933), awareness of the conscience (Greene, 1998), analysis of discourse, dialogue with others, and reflection for deeper understanding and action (Mezirow, 1997; Vygotsky, 1978).

The importance of fostering teachers' transformative learning cannot be underscored given that many teachers who are European Americans, middle-class who view themselves as cultureless, culturally encapsulated, socialized to conservative ideologies and mind frames that negate their abilities to engage in effective cross-cultural and culturally responsive teaching. Scholars in multicultural education have differed over what approaches or pedagogies to be used in engaging preservice and inservice teachers in confronting their beliefs, values, issues of 
power, privilege, policies, and inequities (Nieto, 2005), and yet do so in ways that are counter-productive, demoralizing, and engendering student resistance (Bruch, et al., 2004). This begs the question: how do you foster transformative learning in ways that are humanizing, dialogical, and responsive in a multicultural education course? Scholars of transformative learning suggest that, to teach for transformative learning, one must engage in transformative pedagogy. So, what is transformative pedagogy? Before discussing transformative pedagogy, it is necessary to first define what pedagogy means. Giroux and Simon (1989) define pedagogy as "the integration in practice of particular curriculum content and design, classroom strategies and techniques, a time and space for the practice of those strategies and techniques, and evaluation purposes and methods" (p. 239). Transformative pedagogy has been described as "critical pedagogy" (Freire, 1978; Shor, 1992), "liberatory pedagogy" (Freire, 1978; Greene, 1998; McLaren, 1998), "pedagogy of empowerment," and "activist pedagogy." In this paper, I define transformative pedagogy as activist and agency pedagogy that combines the elements of constructivism and critical pedagogy that challenges the status quo and (Ukpokodu, 2007) promotes a democratic and emancipatory learning context where students and professors engage in dialogic relationships as co-learners, valuing each other's knowledge, empowering each other for transformative intellectualism (meaningful knowledge construction) and change agency (McLaren, 1998; Shor, 1992).

\section{Methodology}

This qualitative study was situated in a graduate course of a teacher education program at one university, located in a Midwestern community of the United States. Data were collected from 45 students who enrolled in the 2006 winter and 2007 summer semesters. There were five males (13\%) and 40 females (87\%). Six (27\%) were African Americans, two (7\%) were Latino Americans, and $38(67 \%)$ were Caucasians. Thirty-three percent of the participants taught at the elementary level while $67 \%$ taught at the secondary level. Participants' ages ranged between 26 and 55 years. The teaching experience of the participants also ranged from three to 20 years. Ninetyfive percent of the participants had not taken a diversity course prior to enrolling in the course. The research question was: What pedagogies foster transformative learning in a multicultural education course? Data were collected from multiple sources such as alternative end-of-course evaluation, course documents, and participant interviews (Marshall \& Rossman, 1999). Students, whose works were used, granted permission through signed consent (Patton, 2000).

1) Alternative Course Evaluation: Participants responded to an alternative, anonymous course evaluation titled, "I need your help! How can I improve on the last day of the course?" This survey, among other questions, asked the following questions:

1) How would you describe your learning experience in the multicultural education course?

2) What pedagogies fostered your learning? List/describe

2) Course Documents: Course documents (Marshall \& Rossman, 1999) of students' work (pre-post autobiographical narratives, analysis and reflection of the book We Can't Teach What We Don't Know, online threaded discussions, journal essays, and email correspondence) were read and analyzed for evidence of transformative learning.

3) Interviews: Six participants were selected through purposive sampling (Patton, 2002) and interviewed. These participants were selected, based on geographic, gender, racial, and teaching characteristics. There were two males and four females. Three (two males and one female) taught in an urban school setting, three females taught in a suburban school setting. These participants consented to participate by responding to the researcher's request for participation. Each interview lasted 45 minutes. Notes were taken, transcribed, shared with the participants, and analyzed for emerging themes.

\section{Findings}

The department's graduate research assistant (GRA) compiled the data from the alternative, anonymous course assessment and interview transcripts. Data analysis was accomplished through thematic coding (LeCompte \& Schensul, 1999). The GRA, a doctoral candidate with background in multicultural education, and I, independently reviewed the compiled list then identified the themes that emerged and compared them. Data from documents were 
analyzed for evidence of changing perspectives. Data analysis began with independent reading (Glaser \& Strauss, 1999) of each data set and analyzing them for emerging patterns and themes using constant analysis (Glasser \& Strauss, 1999). To answer the research question, "What pedagogies fostered participants' transformative learning?" the following five pedagogical practices emerged.

a) Dialogical Relationship in a Learning Community: Overwhelmingly, participants expressed feeling a sense of community, comfort, and collegiality in the course. Participants used specific descriptors to describe the experience_ "the safe environment," "we were like a family," "the respect among class members," "the collective learning," "the open dialogues," "working in partnerships and groups to gain different perspectives," "I trusted the process," "comfortable learning climate—all students felt relaxed." Comments from document and interview data also illuminated the feeling of a learning community.

I liked the learning community that made us feel comfortable discussing "hard" and difficult issues, what you called "the undiscussables" and sharing personal issues. This was why it was so easy for me to share with the class about my racist family and dating out of my race. The check-in activity at each class meeting and frequent partnership activities put everyone at equal level. There was no competition but learning together. I have started to use this strategy in my classes and both my students and I love it. It has increased my students' active participation in class. (Jessy, European American, Winter 2006)

The class was very relaxed and I noticed that everyone felt comforted sharing ideas. The professor modeled openness by sharing personal stories that were enlightening, which signaled to the class that it was safe to share our own stories. Hearing each other's stories was very powerful and made the course rich and interesting. (Shannella, African American, Winter 2006)

b) Writing Pre-Post Narrative Inquiries: In response to the question, "What pedagogies fostered your learning?" participants listed phrases like "writing the reflective narratives that made me get deep into myself, my thinking, and my practice," "the pre-post narratives were truly meaningful, introspective, and transforming; it moved me from my naïve and ignorant stage to a new understanding, although painful that I was in the dark for so long and doing disservice to others," "the pre-post narratives helped me develop a realistic perspective about me, my culture and history, society and education and schooling-had never written one before." The following comment also sheds some light:

As I wrote my post-autobiographical narrative I went back and re-read my pre-narrative. As I read over that paper, which was brief and mostly focused on my family life, it really pointed out to me how much I have never really considered multiculturalism to be a part of my life let alone how my education could have been affected by it. Before taking this course and learning about white privilege and social justice, I would have never considered myself to be privileged. I have always thought of myself, and my family as normal. As I read over my pre-autobiographical narrative I could see that I was too comfortable before. I was comfortable in my ignorance, and unawareness that social injustice is still very prevalent in our society. This course has now empowered me to take these strong feelings of guilt, shame and anger, and turn them into something proactive, instead of reactive. I began by questioning my feelings: I am not sure why I should feel guilty for things that I have no control over, and I think that this is where my anger comes from. I did not pick the color of my skin, I did not pick the family I was born into, I did not pick the neighborhoods I grew up in, I did not choose the schools I went to, I did not decide that my parents could go to college, I did not pick the professions they ended up with. This is the life that I, Clarisa, a white, middle-class, maybe upper class, privileged girl, was born into. So, this is where my struggles have come from. Why should I feel bad, or guilty, or ashamed of who I am, or who I was born into becoming, when I have had no choice in the matter? And finally, at the end of this course, the realization has come. My personal change has come from inside me. From my own racial identity development, from dealing with issues that I have had inside me and interacting with those in class who, like me have been dealing with their own racial identity struggles, and maybe, until this class have been unaware of them and having had the opportunity, for once in my life, to be in such a multi-culturally diverse class, has helped me see how I have been racist and segregated. The point is not to make me feel guilty, or ashamed of who I am, and who I was raised to be, no, the whole idea behind the theories of social justice and social awareness, is just that. To be aware of my power and to use it for good, rather than bad, and to slowly, one student at a time, pass the power on to the next generation of multiculturally aware individuals. (Clarisa, White American, Winter 2006)

c) Engagement and Reflection on Activities: All participants expressed that their engagement in experiential activities such as Alpha-Bafa cultural activity (Ukpokodu, 2002), race to the wall, privilege exercise, and dissecting 
"we the people," engendered deep thinking about themselves, society and their praxis. Participants described their perspectives using phrases such as, "class activities were great," "the cultural simulation and games-race to the wall, privilege walk, role-play, take a stand, alpha-bafa," "simulating disability issues was powerful." In addition to these descriptors, excerpts from participants' pre-post narratives illustrate the value, power, and appreciation for the experiential activities.

I really liked the activity where we started on the same line and then moved based on our cultural and social experiences. I saw the difference between each person and where they stood based on the experiences that they have had. I know that when the exercise was over, I felt guilty about where I was compared to other students in my classroom. I was never made aware of the differences of cultures and the different experiences that they had just based on their race or culture. (Michael, European American Male, Summer 2006).

d) Critical Textual Discourse: Participants indicated that reading and interacting with an array of course materials-required textbooks, articles and video materials, positively impacted their learning transformation. Several phrases and comments participants used to describe the value and power of critical textual discourse include, "texts were excellent-Takaki, Howard, Banks, and Grant and Sleeter." "The books were outstanding; in fact, they now hold a prominent place in my library and I refer to them often," "I love We Can't Teach What We Don't Know," although painful to read." "All the articles were thought-provoking and insightful."

e) Engagement in Structured and Threaded Discussions: Overwhelmingly, participants identified their engagement in both classroom and online threaded discussions as a powerful medium that influenced their learning transformation. In responding to the prompt, "I need your help; how can I improve?" students expressed their perception using the phrases 'the online discussions such as 'Does culture matter in teaching and learning?' 'Can teachers function as culturally responsive teachers and change agents in the era of mandated curriculum and scripted instruction?"' were enlightening and enabled us to share with other students, clarify questions and thinking, and to view others' perspectives and thinking. "The class discussions of the books really helped me to develop a new lens for looking and responding to people." "Discussing the videos really opened my eyes and changed my perspectives about some of the issues - the one on Both of my two moms' names are Judy really blew my mind, and hearing others' perspectives got me really thinking and changed my mind about including gays and lesbian issues in my curriculum." "The discussion of the video on gender bias was unbelievable-I will now be monitoring this in my own teaching."

f) Experiencing Humanizing Pedagogy: Data revealed that participants perceived the humanization of the teaching and learning process as influencing their learning transformation. Participants expressed this by using several phrases: "the professor's humanizing teaching style," "instructor's style-openness and connection with students," "constructive and meaningful feedback-your sensitivity and empathy even when I made naïve and ignorant comments," "the relationship you had with the class," "giving us opportunity to redo assignments and correct our mistakes," "your human presence - the way you greet the class when you walk in, ask about our day, weekend," "You support and encourage dialogue and so democratize the classroom."

\section{Discussion}

First, the findings of this study clearly confirmed the messages participants conveyed to me throughout the course about experiencing transformative learning. Second, participants indicated that the implementation of well-designed pedagogies and activities fostered their learning transformation, which affirms what research suggests, that using specific pedagogies foster learning transformation. The questions I posed to myself as I analyzed the data were: what evidence-supported student learning transformation, if any? Is it possible for students to experience transformative learning in one semester course? The theory on transformative learning suggests that transformation in learning occurs when individuals gain an awareness of their current habits of mind, develop new points of view, critique their underlying assumptions and premises; reconstruct their perspectives and develop new lenses for looking at the world (Dewey, 1933; Mezirow, 2000). Based on the data analysis, I submit that the participants experienced transformative learning. Participants used the language of transformation to describe their learning"the course was eye-opening; it changed my perspectives," "I have moved from color-blindness to color-vision," "no longer sheltered." Through the process of reading and analyzing the pre-post narrative inquiries, I was able to observe the learning transformation of each participant. In the post-narrative inquiry, participants identified gaps in their knowledge and development, and re-wrote their narratives to reflect new knowledge, understanding, and 
shifting perspectives about self, society, and praxis. In these narratives, many participants expressed painful experiences in their understanding of racial/cultural identity and envisioned plans to adjust their dispositions and practice to make them more humane, democratic, equitable, and just. These participants experienced what Mezirows (1991, p.167) defined as "perspective transformation" whereby [individuals] become critically aware of how and why our assumptions have come to constrain the way we perceive, understand, and feel about our world; changing these structures of habitual expectation to make possible a more inclusive, discriminating, and integrating perspective; and, finally, making choices or otherwise acting upon these new understandings."

Third, scholars of transformative learning have identified specific practices that foster transformational learning, such as trusting relationship within the learning context, experiential activities; opportunities for critical reflection, rational discourse, shared and collective learning, and critical content (Cranton, 2006; Dewey, 1966; Mezirow, 1997, 2000; Taylor, 2000). This study found much support for such pedagogies. The learning community, the role and modeling of the professor are critical to creating and fostering open and safe spaces for dialoguing and learning about complex and hard issues of diversity and social justice. Knowles (1980) suggests that setting up an appropriate learning climate is key to establishing a successful learning experience. He described such a climate as one "which causes [learners] to feel accepted, respected, and supported, and friendly" (p. 47). Participants valued the opportunity to learn in a safe environment that allowed them to take risks and become open to new and different perspectives. Fostering dialogical and dialectical relations between and among professor and students and humanizing the learning context are at the heart of transformative pedagogy and learning. Transformative scholars emphasize the importance of the instructor's role in designing a learning environment characterized by trust and caring, and sensitive relationships (Taylor, 1998) and "a community of knowers" where participants are co-learners and "united in a shared experience of trying to make meaning of their life experience" (O'Loughlin, 1991, pp.320321). In the course, collaborating with the class, community norms were developed that guided members' conduct. Additionally, throughout the course, all learning experiences were facilitated either in partnership/paired learning activities or in teams, which allowed students to interact, dialogue, question, learn from each other, and build respectful relationships. Social constructivists emphasize, that social interactions in a mutually respectful context help students learn from the viewpoints of others and meaning negotiated from multiple perspectives (Vygotsky, 1981). Throughout the course students were assured that their voices were valued. At the start of each class, students were invited to "check in" by sharing their readings, questions, and issues. This comment captures the sentiment of the participants' value for their empowerment through voicing:

\begin{abstract}
The check-in process was one of the routines I found to be very important. This open forum often led to serious discussions of concerns that we faced as teachers. During the check-in process we learned of teachers' fears in teaching outside of their cultures. We also learned that black teachers were not comfortable in teaching in all white districts just as white teachers were uncomfortable in teaching in all black urban districts. The check-in process uncovered the naivety of some that thought being color blind was a way of showing that you are not racially prejudice, not realizing the importance of seeing color and acknowledging differences. Discussions about the guilt placed on white teachers for past racial injustices was another checkin that stirred conversations on trust and responsibility and resulted in teachers understanding the images that they represent and their obligation to change those images through trust and respect.
\end{abstract}

Fourth, creating and fostering opportunities for student engagement in rational discourse is crucial to fostering transformative learning. Rational discourse allows learners to openly discuss and challenge their beliefs with their peers (Caffarella \& Merriam, 1999; Mezirow, 1990, 1991; Taylor, 1998), which engenders critical reflection. Research suggests that engaging students in open discussions and dialogues about diversity issues helps them develop new perspectives and critical reflection (Nieto, 2008; Parker, 2003; Barton and Levstik, 2004). During the course much of the rational discourse was facilitated through structured and online threaded discussions as students openly communicated their ideas and challenged each other's perspectives. In addition, requiring multiple texts that engage students in critical discourse, allows them to be exposed to different views that challenge their thinking. Students need to be exposed to a variety of texts that provide different intellectual challenge and perspectives. As Applebees (1996) suggests, curriculum as conversation "offers a way to think about the problems and possibilities of multiculturalism in our increasingly pluralistic world" (p.127). Although participants were overwhelmed by the number of texts required in the course, they valued them for fostering their learning transformation.

Fifth, immersing and actively engaging students in experiential learning activities proved to be powerful in facilitating students' transformative learning. Activities such as the bafa-alpha (Ukpokodu, 2002), race to the wall/the privilege walk were expressed as profoundly powerful in stimulating student's self-reflection and thinking. Debriefing each activity and challenging students to write about the experience is critical to effecting change in 
perspective. As one participant mentioned during the interview, "the most critical aspect of the course for me, was the challenge you built into it. Your course is not fluff like many other courses I have taken. You challenge students to dig deep into their thinking, themselves, but you also scaffold our learning." Also, consider this comment:

I like the fact that you empowered us to step up and become "experts" in teaching and learning in the course. The "expert" presentation really made me read the materials with great concentration, understanding, and thinking. It was a challenge to orally present in front of my peers but that was what motivated me to delve into the material. I could never have been convinced about the colorblindness perspective had I not presented on the chapter. Now as a sixth grade teacher of social studies and communication arts, I have started using the strategy. My students love the idea and refer to themselves as "experts." This was very powerful for me.

Sixth, this study ascertained the power of reflection in influencing participants' awareness of their assumptions (Cranton 2006) and shift in perspective. As research suggests, reflection, narratives, and autobiographies represent ways we come to know who we are and are validated; and powerful ways of knowing and improving self and practice. As McEwan and Egan (1995) explain, narrative is "essential to the purpose of communicating who we are, what we do, how we feel, and why we ought to follow some course of action rather another...to our efforts to understand teaching and learning" (p. xiii).

As presented in the findings, participants found the pre-post narratives profoundly valuable to their learning transformation, by enabling them to get deep about self, thinking, and praxis and moving from the state of naïveté and ignorance to a new and reconstructed understanding. Challenging learners to respond to critical questions on assignments is essential to achieving critical reflection. For example, the pre-post narrative inquiries required participants to discuss their culture, cultural socialization and cultural/racial identity, how they had been constructed; impact on their thinking about human diversity, multicultural America, educational equity, and diverse student populations. The book analysis required participants, to reflect on the pre-narrative inquiry and to discuss specific gaps/challenges that the author revealed about their personal and professional development that needed to be addressed in order to cultivate the habits and minds of transformative practice. As one participant mentioned, "I must say that this course has really helped me to develop my habit of reflection. How couldn't anyone in this class! In each assignment, you always raise questions that force us to think deeply and to connect what we are learning to our lives."

Finally, most people would argue that it is difficult, if not impossible, for students to experience transformation in learning based on one university course. But scholars of transformative learning believe that it is possible, and remind us that transformation can occur in discrete classes because transformation comes in different sizes that may entail "a moment of transition from passivity to naiveté to some animation and critical awareness" (Shor, 1987, p.34). Further, Shor (1987) warns us that in "looking only for big changes, [we] lose touch with the transformative potential in any activity" (p.35). The process of transformation may occur in stages. University courses can at least provide an avenue for understanding the nature of society as a contested terrain (Freire \& Shor, 1987). As Freire (1987) also suggests, "for transformation, we need first of all to understand the social context of teaching, and then ask how this context distinguishes liberating education from traditional methods" (p.33). That is, the transformative focus may become one of first, developing critical knowledge and a lens for reflecting and then making plans for action. Thus, for me, the students' development of self, a new awareness of societal and educational reality, and praxis is a form of learning transformation. Freire (1987) suggests that, in the final analysis, liberatory education must be understood as a moment or process or practice where we challenge people to mobilize or organize themselves to get power. I would submit that participants in this course were engaged in the moment, and even process of organizing to gain power. Through varied opportunities for authentic learning, rational discourse, and collaborative learning, the participants embraced the challenge of self-examination and reframed their limited prior perspectives about self, society, and humanity while developing insights and theory about praxis (Giroux, 1992; McLaren (1998). Additionally, I believe that, students who have been empowered by new knowledge have the potential to envision personal and social transformation. Some of the students in this study had begun to envision transformative practice and agency. During the interview some participants shared about their passion and plans for change agency such as classroom curricular and pedagogical transformation, serving on committees for textbook adoption and professional development and advocacy. Consider this comment:

As I look back on the autobiographical narrative that I wrote during the first week of class, I am reminded of the vast knowledge that I have gained during this course. Although I work in a suburban school setting where multicultural education is viewed as irrelevant because of lack of diversity in the student population, I have started to take some action. In order to help facilitate the change and become a change agent, I have volunteered to serve on the textbook selection committee for our school district. Each year we have an 
adoption committee for whatever subject area is up to be renewed. I am now a volunteering member on that committee. I feel that one of the most valuable lessons that I have learned from this class is to not make assumptions but to see everyone's perspective. I will be using this knowledge as I work on the committee and to make sure that textbooks provide multiple perspectives and have multiple representations of cultures. (Meddy, European American, winter 2006)

As I reflect on these pedagogies and the experiences of the students, it is easy to suggest that the course was empowering and successful. While I agree that the course was transforming for both professor and students, it will be misleading to say that everything was "perfect." I still had a few students (five) who exhibited passive resistance. For example, two students resulted to plagiarism in one assignment in which they were to analyze the book We Can't Reach What We Don't Know. The students expressed to me that they were "literarily sick as they read the first three chapters that made them feel guilty and ashamed of being white." However, this experience was still positive for the student as she realized, upon reflection, that she did not have what it takes to teach diverse students and so decided to resign from teaching. In addition, the challenge and cost of practicing transformative pedagogy can be emotionally unsettling. Transformative pedagogy forces the professor to "walk the talk." This includes walking the fine line of challenging students' misguided views while being cognizant of the need to value and respect their developing self and journey. In addition, engagement in transformative pedagogy is very challenging in terms of the amount of work that is needed to develop and facilitate authentic activities that foster meaning-making, perspective consciousness, and reflection. Finally, I must emphasize that the pedagogies discussed in this study are not necessarily new. However, there was no attempt to determine other experiences that may have contributed to participants' learning transformation. Given the small size of the study sample and localized population, the ability to generalize the findings is limited. Nevertheless, the findings reveal important insights that are worthy of consideration as teacher educators work to prepare teachers for diversity and multicultural teaching.

\section{Conclusion}

The importance of preparing teachers for transformative learning cannot be emphasized enough. If the persistent achievement, learning, and community gaps ((Lee, 2005) are to be closed, and if we are to foster a multicultural democracy, we need teachers who possess the habits and minds of transformative practice. As Howard (2006, p 127) warns us "an unexamined life on the part of a White teacher [or any educator] is a danger to every student." To facilitate successful learning in multicultural education courses, professors must be proactive and engage in pedagogies that are empowering, humanizing, and liberating yet engaging enough to foster meaningful knowledge construction and yet critical enough to challenge students' conservative and myopic beliefs and values. I conclude by sharing one participant's comment that illuminates the need and importance for multicultural education and transformative learning.

I did not see any need for multiculturalism in my school and teaching. I teach in a suburban school community. Many of the students are from wealthy families, you know, middle class and upper class. Their parents value education and take it seriously. The students know why they are in school. The parents are very active in their children's education. The students work hard to earn good grades to please their parents. The minority students in my school and class are also from middle class families. They do well although not as well as the white students. So, generally, teachers do not think of multiculturalism. I did not think of it until this semester. I do teach about certain holidays during the season. That is all I did. I did not see the need to teach in a different style. I have never considered teaching in a different way. As a matter fact, I have never thought of multiculturalism having a role in a suburban school community. Students and teachers are of similar background-race and class wise. However, after completing this multicultural education course, I realize that multiculturalism is much needed in suburban schools, if not more. Multiculturalism belongs in suburban school communities. More importantly, I now realize that, even as a white teacher, I have a role in multiculturalism. This is my most transformational experience from the course. (Jenny, European American)

\section{References}

Ahlquist, R. (1991). Position and imposition: Power relations in a multicultural foundations class. Journal of Negro Education, 60 (2), 158-169.

Applebee, A. (1996). Curriculum as conversation. Chicago, IL: University of Chicago Press.

Barton, J. A. \& Levstik, L. S. (2004). Teaching history for the common good. Mahwah, NJ: Lawrence Erlbaum.

Cranton, P.A. (2002). Teaching for transformation. New Directions for Adult and Continuing Education, 93, 63-71. 
Cranton, P.A. (2006). Understanding and promoting transformative learning: A guide for educators of adults. San Francisco: Jossey-Bass.

Dewey, J. (1933). Experience and education. New York: Macmillan Publishing Co.

Gay, G. (2003). Preparing teachers for culturally responsive teaching. Journal of Teacher Education, 53(2), 106116.

Glaser, A. \& Strauss, B. (1999). The discovery of grounded theory: Strategies for qualitative research. Chicago: Aldine Publishing.

Giroux, H. (1988). Teachers as intellectual: Toward of critical pedagogy of learning. Boston, MA: Bergin \& Garvey Publications.

Giroux, H. \& Simon, I (1992): Schooling, popular culture, and pedagogy of possibility. In K. Weiler \& C. Mitchell (Eds.), What schools can do: Critical pedagogy and practice.

Greene, M. (1998). Introduction: Teaching for social justice (xxvii-xlvi). In W. Ayers, J. A. Hunt, \& T. Quinn (eds.), Teaching for social justice. New York: The New Press.

Haberman, M. (1991). Can cultural awareness be taught in teacher education programs? Teacher education, 4 (1), 25-31.

Howard, G. (2006). We can't teach what we do not know: White teachers, multicultural schools. New York: Teachers College Press.

Jarvis, P. (1999). The Practitioner-Researcher. San Francisco: Jossey-Bass.

Ladson-Billings, G. (1991). Coping with multicultural illiteracy: A teacher education response, Social Education, 55(3): 186-89.

Ladson-Billings, G. (2000). Preparing teachers for diversity. In L. Darling-Hammond \& G. Sykes (eds.), The teaching and learning profession. San Francisco: Jossey-Bass.

Larke, P. (Fall 1990). Cultural diversity awareness inventory: Assessing the sensitivity of preservice teachers. Action in Teacher Education, 12 (3), 23-30.

Lecompte, M., \& Shensul (1999). Designing and conducting ethnographic data (Ethnographer's toolkit, vol 5). Walnut Creek, CA: Alta Mira Press/Sage.

McEwan, H. and Egan, K. (1995). Narratives in teaching, learning and research. New York: Teachers College Press.

McLaren, P. (1998). Revolutionary pedagogy in post-revolutionary times. Educational Theory, 48 (4), 431-462.

Miron, L. F. and Miles, L. (1998). Student voices as agency: Resistance and accommodation in inner-city schools. Anthropology and Education Quarterly, 29 (2), 189-213.

Marshall, C., \& Rossman, G. (1999). Designing qualitative research. Thousand Oaks: Sage.

Mezirow, J., \& Associates (2000). Learning as transformation: Critical perspective on a theory in progress. San Francisco: Jossey-Bass.

Mezirow, J. (1997). Transformative learning: Theory to practice. In P. Cranton (Transformative learning in action: Insights from practice. New directions for adult and continuing education (pp. 5-12), NO. 74 . San Francisco, CA: Jossey-Bass.

Mezirow, J. (1991). Transformative dimensions of adult learning. San Francisco, CA: Jossey-Bass.

Nieto, S. (1999). The light in their eyes: Creating multicultural learning communities. New York: Teachers College Press.

Nieto, S. (2000). Placing equity front and center: Some thoughts on transforming teacher education for a new century. Journal of Teacher Education, 51 (3): 180-187.

Nieto, S. \& Bode, P. (2008). Affirming diversity: The sociocultural context of multicultural education (5 $5^{\text {th }}$ Edition). Boston: Pearson \& Allyn \& Bacon.

O'Loughlin, M. (1991). Beyond constructivism: Toward a dialectical model of the problematic of teacher socialization. (ERIC Document Reproduction Service No. ED 338 559).

Patton, M. (2000). Qualitative research \& evaluation methods. Thousand Oaks.

Shor, I., \& Freire, P. (1987). A pedagogy of liberation: Dialogues on transforming education. New York: Bergin and Garvey.

Tatum, B. D. (1992). Talking about race, learning about racism: The application of racial identity development theory. Harvard Educational Review 62 (1): 1-24.

Taylor, E. (1998). The theory and practice of transformative learning: A critical review. Information Series NO. 374. Columbus: ERIC Clearinghouse on Adult, Career, and Vocational Education. Center on Education and Training for Employment. College of Education, the Ohio State University.

Taylor, E.D. (2000). Fostering Mezirow's transformative learning theory in the adult education classroom: A critical review. Canadian Journal for the Study of Adult Education, 14(2), 1-28. 
Ukpokodu, N. (2002, Spring). Breaking through Preservice Teachers' Defensive Dispositions in a Multicultural Education Course: A Reflective Practice. Multicultural Education, 9 (3): 25-33.

Ukpokodu, O. N. (2004, Fall). The Impact of shadowing culturally different students on preservice teachers' dispositions toward diverse students, Multicultural Education, 12 (2): 19-28.

Ukpokodu, O. N. (2007, Winter). Fostering transformative learning in a social studies methods course: A reflection on transformative pedagogy. Social Studies Research and Practice, 2(3): 316-340.

Vygotsky, L. (1978). Mind in Society: the development of higher psychological processes. Cambridge, MA: Harvard University Press.

Wiessner, C.A. \& Mezirow, J. (2000). Theory building and the search for common ground. In J. Mezirow \& Associates (Eds), Learning as transformation: Critical perspectives on a theory in progress. San Francisco: Jossey-Bass. 